\title{
Pigmentary retinopathy masked by asymmetric acquired phenomena
}

\author{
Kit Green Sanderson, ${ }^{1}$ Kirk A J Stephenson (10, ${ }^{2}$ Adrian Dockery, ${ }^{2}$ David J Keegan ${ }^{2}$
}

${ }^{1}$ School of Medicine, Royal College of Surgeons in Ireland, University of Medicine and Health Sciences, Dublin, Ireland ${ }^{2}$ Ophthalmology Department, Mater Misericordiae University Hospital, Dublin, Ireland

\section{Correspondence to}

Dr Kirk A J Stephenson; kirkstephenson@hotmail.com

Royal Academy of Medicine in Ireland, Ophthalmology Division, Winter Meeting 2018

Accepted 15 October 2021
Check for updates

(c) BMJ Publishing Group Limited 2021. No commercial re-use. See rights and permissions. Published by BMJ.

To cite: Green Sanderson K, Stephenson KAJ, Dockery A, et al. BMJ Case Rep

2021:14:e246982.

doi:10.1136/bcr-2021-

246982

\section{DESCRIPTION}

A 49-year-old woman was referred to the retina clinic with incidentally noted retinal pigmentation. She had long-standing poor left visual acuity (VA) due to a compressive optic neuropathy treated by surgery in childhood. She also had chronic angle closure glaucoma, treated with bilateral laser peripheral iridotomies (PIs) and left lensectomy. She was otherwise healthy with no active other medical conditions.

On examination, VA was $6 / 9.5$ and $6 / 24$ in right and left eyes, respectively. She had a left relative afferent pupillary defect, patent bilateral PIs, left pseudophakia and intraocular pressure of $12 \mathrm{~mm} \mathrm{Hg}$ bilaterally. There was no evidence of intraocular inflammation. While the right optic disc was normal, the left eye had significant cupping and pallor. There was symmetrical perivascular nummular pigmentation with associated chorioretinal atrophy most notable at the superotemporal vascular arcades (figure 1A,B). Autofluorescence imaging highlighted the extent of retinal pigment epithelial (RPE) atrophy in the same distribution, with less marked mottling of RPE autofluorescence nasally (figure 1C,D). Optical coherence tomography showed preserved foveal photoreceptor structures, no macular oedema/schisis and absent retinal nerve fibre layer in the left eye, in keeping with advanced optic neuropathy. Static perimetry showed advanced visual field loss in the left eye likely due to the advanced optic neuropathy and an early ring scotoma in the right eye more marked inferiorly in keeping with the distribution of retinal atrophy (figure 2A,B). Rod responses were absent on full field electroretinogram and cone responses were delayed and attenuated with the pathognomonic bright flash a-wave amplitude greater than $30 \mathrm{~Hz}$ flicker amplitude. Panel-based next-generation sequencing (NGS) detected a homozygous likely pathogenic mutation (c.305C >A,p.Ala102Asp) in the NR2E3 gene (15q23) which has been reported as responsible for autosomal recessive enhanced S-cone syndrome (ESCS), also known as Goldmann-Favre syndrome.

Confirmation of genotype is relevant as novel gene therapies are under investigation for multiple inherited retinal degenerations (IRDs); panel-based NGS investigation genetically resolves IRD pedigrees in $>70 \% . .^{12}$ ESCS is a disorder of photoreceptor differentiation in which short-wavelength sensitive cone photoreceptor (S-cone) progenitors fail to fully differentiate into rods or long/medium

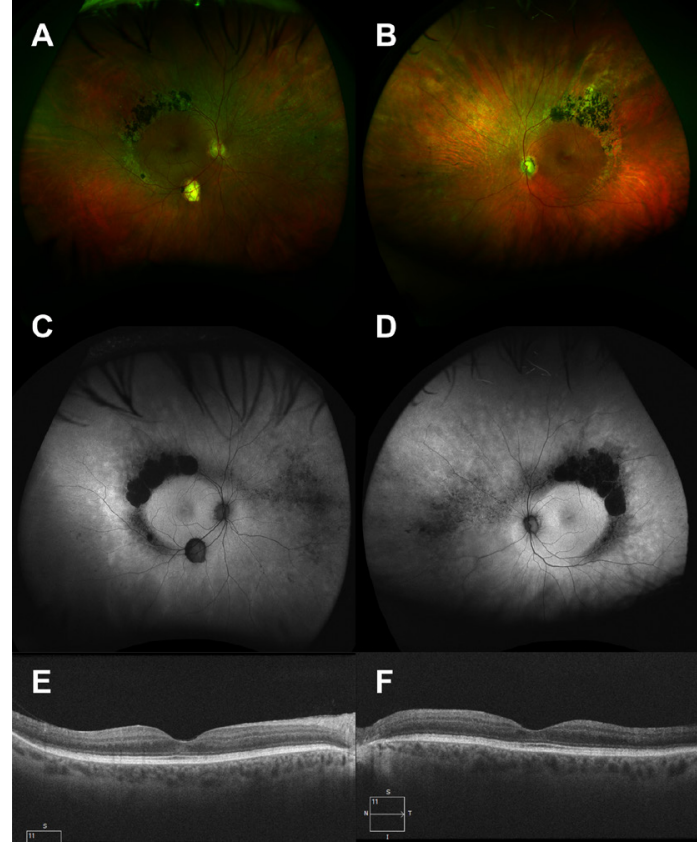

Figure 1 Widefield colour Photographs (T200x camera, Optos plc, UK) of the right (A) and left (B) eyes showing predominantly superotemporal perivascular nummular pigmentation and outer retinal atrophy/ pallor. There are subretinal white dots and less marked intraretinal pigment hypertrophy nasally. The left optic disc shows cupping and pallor and there is an isolated area of retinal pigment epithelial (RPE) atrophy at the right inferotemporal vascular arcade. Widefield autofluorescence imaging (T200x camera, Optos plc, UK) of right (C) and left (D) eyes delineates the extent of RPE atrophy, revealing hyperautofluorescent areas peripherally throughout the fundus with preserved macular isoautoflourescence. Optical coherence tomography (Cirrus 5000, Carl Zeiss MediTec, Dublin, California, USA) shows preservation of the photoreceptor layers within the macula $(E, F)$.

wavelength-sensitive cone photoreceptors ${ }^{3}$ supported by pathological (double normal cone number, 12 million per eye, with $92 \%$ staining for S-cone markers) ${ }^{4}$ and electrophysiological (absent rod responses and $30 \mathrm{~Hz}$ amplitudes less than photopic bright flash a-wave $)^{5}$ evidence. ESCS is caused by mutations in the NR2E3 gene (or rarely the NRL gene ${ }^{6}$ ) with 53 known pathogenic or likely pathogenic variants reported. Most NR2E3 variants cause ESCS while a single variant (c.356G >A,p.Gly56Arg) manifests as an autosomal dominant retinitis pigmentosa phenotype. ${ }^{78}$ ESCS is rare, with less than 1000 


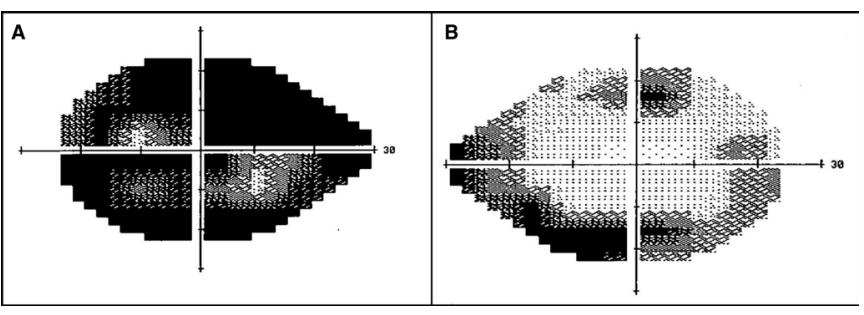

Figure 2 Static visual fields (24-2, Humphrey field analyzer, Carl Zeiss MediTec, Dublin, California, USA) showing advanced reduction in sensitivity of left eye (A) due to multifactorial optic neuropathy, while the right eye (B) has an incomplete ring scotoma corresponding to the outer retinal atrophy at the vascular arcades.

cases reported in the literature. Symptoms are typically early night blindness ( $\sim 4$ years), but this may be masked by other disease. ${ }^{5}$ At a mean of 26.6 years, VA was $\geq 6 / 12$ in $57 \%$ of eyes, with $66 \%$ of patients meeting VA standards for driving and only $7 \%$ considered legally blind. ${ }^{5}$ Gradual progression (six letter loss over 6 years) is reported in only $21 \%{ }^{5}$ and retention of visual field has been demonstrated. ${ }^{9}$ There is no approved genetic therapy to date; however, confirmation of an NR2E3 genotype aids prognostication.

\section{Learning points}

- Primary photoreceptor disease may be masked by other pathologies, whether systemic (eg, intellectual disability in syndromic inherited retinal degeneration (IRD)) or ocular (eg, optic neuropathy).

- Autofluorescence imaging is invaluable in assessing the health of the retinal pigment epithelium, helping to delineate symmetry and extent/severity of disease

- Although therapies are not yet available/approved for most IRDs, some conditions are entirely/largely stationary and may benefit from genetic diagnosis for prognostic and family planning, and may allow access to future gene therapy.
Twitter Kirk A J Stephenson @KarkStaphonsen and Adrian Dockery @docdockgoose

Acknowledgements Fighting Blindness Ireland. We thank the patient for consenting to share their case, understanding that their story could provide valuable insight for other healthcare practitioners in the field.

Contributors KGS contributed to the manuscript construction as well as aspects of the literature review. KAJS handled patient care, obtained consent, obtained imaging and approached me about writing up this case. AD was in charge of the genetic analysis and DK oversaw the entire project. All authors contributed to editing and formatting of the final manuscript.

Funding The authors have not declared a specific grant for this research from any funding agency in the public, commercial or not-for-profit sectors.

Competing interests None declared.

Patient consent for publication Consent obtained directly from patient(s)

Provenance and peer review Not commissioned; externally peer reviewed.

ORCID iD

Kirk A J Stephenson http://orcid.org/0000-0002-7462-7725

\section{REFERENCES}

1 Dockery A, Stephenson K, Keegan D, et al. Target 5000: target capture sequencing for inherited retinal degenerations. Genes 2017;8. doi:10.3390/genes8110304. [Epub ahead of print: 03 Nov 2017].

2 Whelan L, Dockery A, Wynne N, et al. Findings from a genotyping study of over 1000 people with inherited retinal disorders in Ireland. Genes 2020;11. doi:10.3390/ genes11010105. [Epub ahead of print: 16 Jan 2020].

3 Haider NB, Jacobson SG, Cideciyan AV, et al. Mutation of a nuclear receptor gene, NR2E3, causes enhanced S cone syndrome, a disorder of retinal cell fate. Nat Genet 2000;24:127-31.

4 Milam AH, Rose L, Cideciyan AV, et al. The nuclear receptor NR2E3 plays a role in human retinal photoreceptor differentiation and degeneration. Proc Natl Acad Sci U SA 2002;99:473-8.

5 de Carvalho ER, Robson AG, Arno G, et al. Enhanced S-cone syndrome: spectrum of clinical, imaging, electrophysiologic, and genetic findings in a retrospective case series of 56 patients. Ophthalmol Retina 2021;5:195-214.

6 Littink K, Stappers P, Riemslag F, et al. Autosomal recessive NRL mutations in patients with enhanced S-cone syndrome. Genes 2018;9:68.

7 Gire Al, Sullivan LS, Bowne SJ, et al. The Gly56Arg mutation in NR2E3 accounts for $1-2 \%$ of autosomal dominant retinitis pigmentosa. Mol Vis 2007;13:1970-5.

8 Landrum MJ, Lee JM, Benson M, et al. ClinVar: improving access to variant interpretations and supporting evidence. Nucleic Acids Res 2018;46:D1062-d7

9 Garafalo AV, Calzetti G, Cideciyan AV, et al. Cone vision changes in the enhanced $\mathrm{S}$-cone syndrome caused by NR2E3 gene mutations. Invest Ophthalmol Vis Sci 2018;59:3209-19.

Copyright 2021 BMJ Publishing Group. All rights reserved. For permission to reuse any of this content visit

https://www.bmj.com/company/products-services/rights-and-licensing/permissions/

BMJ Case Report Fellows may re-use this article for personal use and teaching without any further permission.

Become a Fellow of BMJ Case Reports today and you can:

- Submit as many cases as you like

- Enjoy fast sympathetic peer review and rapid publication of accepted articles

- Access all the published articles

Re-use any of the published material for personal use and teaching without further permission

Customer Service

If you have any further queries about your subscription, please contact our customer services team on +44 (0) 2071111105 or via email at support@bmj.com.

Visit casereports.bmj.com for more articles like this and to become a Fellow 